\title{
SISTEM DEMOKRASI DI INDONESI DALAM PERSFEKTIF HIZBUT TAHIR INDONESIA
}

\author{
Zaenal Abidin \\ Universitas Islam Negeri Mataram \\ zabdiee@yahoo.com
}

\begin{abstract}
Abstrak
Negara demokrasi dikonotasikan sebagai suatu cara pandang yang memberikan kebebasan kepada setiap orang untuk berpendapat, berpikir, berkarya hatta kebebasan dalam memeluk suatu agama dan ajaran tertentu menurut keyakinan mereka masing-masing. Indonesia dalam hal ini di sebut-sebut sebagai negara yang mengadopsi paham demokrasi dalam sistem pemerintahan yang "dilakoninya", sehingga berimbas pada pola, sistem dan ketetapan yang mampu merangkul setiap etnis, budaya, suku, agama dan kepercayaan setiap warga negaranya, sebagaiman yang diamanatkan oleh UUD 45 dan pancasila sebagai dasar Negara. Kebebasan dalam beragama berimplikasi pada "agama minoritas" dan "agama mayoritas". Agama "Islam" merupakan salah satu agama yang "digandrungi" (baca: mayoritas) di Indonesia; ajaran baku (syariat Islam) sering kali tidak sejalan (baca: berbenturan) dengan idelogi Negara. Para 'abdi agama' menghendaki syariat Islam sebagai rujukan dalam melaksanakan sistem pemerintahan, terutama dalam penetapan hukum sebagaimana yang "dikumandangkan" bahwa Islam adalah agama rahmatan lil alamiin. Hizbut Tahrir sebagai penggagas idiologi ini mengambil tempat dalam sistem perpolitikan di Indonesia. Idiologi yang dikembangkan bermuara pada model khilafah yang pernah diperankan oleh Nabi saw, Khulafaur Rasyidin dan khalifah-khalifah setelahnya. Gagasan Hizbut Tahrir mengenai khilafah Islamiyah atau daulah Islamiyah, meskipun masih jauh dari harapan, tetapi bermanfaat bagi pendidikan politik umat Islam.
\end{abstract}

Kata Kunci: Demokrasi, Hizbut Tahrir, Politik 
Komunike, Volume XI, No. 1, Juni 2019

\section{A. Latar Belakang}

Tidaklah mudah mengaitkan Islam dengan demokrasi akan tetapi tidak sedikit muslim yang berpandangan bahwa Islam sejalan dengan demokrasi. Indonesi adalah negara yang belandasan pancasila dan kebinekaan, sebagian besar penduduknya mayoritas Islam. Meskipun demikian Indonesi bukanlah sebuah negara Islam seperti negara yang ada di timur tenangah kebanyakan walapun Islam tidak disebutkan dalam konstitusi negara Indonesi akan tetapi Islam mempunyai peran yang sangat penting dalam tatanan kehidupan sosial dan politik. Semenjak Islam masuk dan tersebar luas di dataran Indonesi dan membentuk sebuah kerajaan Islam pada akhir abad ke 13,Islam telah menjadi salah satu sumber dalam pembentukan nilai, norma dan tingkah laku rakyat Indonesia. Dalam proses pembangunan politik modern terutama dipengaruhi oleh gagasan modernisme Islam. Kaum modernis adalah mereka yang melauka artikulasi dan upaya penyadaran untuk merepormulasikan nilai-nilai dan prinsip-prinsip Islam dalam istilah pemikiran modern atau untuk menyatukan pemikiran dan institusiinstitusi modern dengan tradisi islam. Salah satu sistem politik Islam yang sering diperbincangkan di negara Islam adalah istilah "demokrasi" istilah ini telah diterima oleh hampir semua pemerintah di dunia; bahkan pemerintah-pemerintah otoriterpun menggunakan atribut "demokrasi" untuk memberi ciri kepada rezim dan aspirasi mereka. Akibatnya adalah menjamurnya penggunaan kata "demokrasi", seperti "domokrasi liberal", "demokrasi terpimpin", "demokrasi kerakyatan", demokrasi sosial". Perubahan penggunaan semacam itu sebagian dimasud untuk membawa konsep demokrasi lebih dekat kepada kultur masyarakat tertentu dan sebagian lagi dimaksudkan utnuk menjustifikasi sistem poltik yang diajukan oleh pemerintah tertentu. Di Indonesi ada tiga konsep demokrasi dalam sejarah politiknya "demokrasi liberal" atau "demokrasi parlementer" (1950-1958), 
Komunike, Volume XI, No. 1, Juni 2019

“demokrasi terpimpin" (1959-1965), dan "demokrasi pancasila" (1966 hingga sekarang), demorasi pancasila di ajukan oleh pemerintah orde baru yang mulai berkuasa sejak tahun 1966. $^{1}$

Demokrasi suatu sistem pemrintahan periodik di Indonesi lima tahun dan di Amerika Serikat empat tahun selama itu presiden tidak dijatuhkan. Pada kesempatan lain cak nur juga menjelaskan demokrasi sebagai majority rule, minority sight, sebuah sistem politik mayoritas dengan tidak mengganggu kepentingan atau hak-hak minoritas yang paling fundamental. Dalam konteks budaya, demokrasi bukan lagi kata benda, tetapi kata kerja, sebagai proses demokratisasi. $^{2}$

"Indonesia" umat Islam telah bekerja untuk membangun negara yang dapat menegakkan keadilan dan menjamin hak-hak setiap individu

1 Masykuri Abdullah, Demokrasi Dipersimpangan Makna Respon Intelektual Muslim Indonesia Terhadap Konsep Demokrasi 1966-1993, (Yogyakarta: Tiara Wacana, 1999), hal. 13.

2 Sukron Kamil, Islam dan Politik di Indonesia Terkini, (Jakarta: PSIA UIN Jakarta, 2013), Hal. 135. dalam kehidupan sosial, poltik, dan negara. Ajaran agama terutama Islam, menentang keras praktik bernegara yang sewenang-wenag, peraktik yang menyimpang dan prilaku aktor negara yang bertentangan dengan nilai-nilai sosial budaya bangsa karena Indonesi adalah masyarakat yang sifatnya plural societies (masyarakat majemuk) sebagai ideal type masyarakat Indonesi yang berbeda dengan negara Islam yang ada berada dibelahan bumi yang lain. Indonesi adalah salah satu bentuk negara demokrasi, akan tetapi demokrasi di Indonesi tidak mencerminkan bentuk demokrasi. Kita ketahui demokrasi adalah suatu yang menjadi landasan atau ciri sebuah negara berlandaskan kebebasan penuh kepada masyaraatnya, ntah itu soal agama, politik, maupun kebudayaan.

Memang selama ini Islam dikembangkan dengan sifat too politically and middle east oriented. Kedua kecendrungan tersebut membawakan beberapa sisi kelemahan sejarah Islam. Orientasi politik merekonstruksi kehidupan elite politik dan pola-pola perebutan 
Komunike, Volume XI, No. 1, Juni 2019

kekuasaan, peperangan dan ulama sebagai penasehat resmi pertumpahan darah yang akhirnya eksklusif atau bahkan pemegang menegaskan citra Islam sebagai kekusaan tertinggi, bagi pemikir politik "agama warior" (agama perang), Islam, Islam bukan sekedar agama bukan sebagai agama rahmat. dalam pengertian barat yang sekuler, Orientasi tersebut juga mengabaikan akan tetapi merupakan suatu pola kesejarhan aspek-aspek kultural hidup yang lengkap dengan seperti pendidikan, perekonomian, pengaturan untuk segala aspek keberagamaan, dan lainnya. kehidupan, termasuk politik.

Sementara orientasi timur tengah Politik muslim melibatkan mereduksi pengetahuan kita dari perlombaan dan persaingan penafsiran perkembangan sejarah dibelahan simbol dan kontrol atas lembaga, baik dunia muslim lainya seolah-olah ia formal maupun informal, yang menjadi satu-satunya model sejarah membuat dan mempertahankan Islam yang tunggal yang akhir simbol-simbol dan lembaga tersebut. menegaskan bingkai sejarah Islam Penafsiran simbol-simbol dilakukan yang sempit yang tidak mengenal dengan menghadapkan dengan latar keragaman. $^{3}$ belakangnya yang sementara bisa

Keterlibatan Islam dalam hal ini dipengaruhi nuansa kontekstual biasa sebagai agama sekaligus Negara (Din bagi muslim diseluruh dunia. ${ }^{4}$ Sistem wa-Daulah) merupakan agama politik, baik di dunia muslim atau sempurna dan antara Islam dan dimanapun, tidak bisa menghindari Negara merupakan dua entitas yang manajemen persaingan bahkan selalu meyatu. Hubunganlslamdan Negar identik di tunggangi dengan benar-benar organik dimana Negara kepentingan. berdasarkan syari'ah Islam dengan

${ }^{3}$ Ghufron A. Mas'adi Sebagai Pengantar Penerjemah Dalam Ira. M. Lapidus, Sejarah Sosial Umat Islam (Jakarta: PT RajaGrafindo Persada, 1999).

${ }^{4}$ Dale F. Eickelman dan James Piscatori, Politik Muslim; Wacana Kekuasaan dan Hegemoni Dalam Masyarakat Muslim, (Yogyakarta: Tiara Wacana, 1998), hlm. 6. 
Komunike, Volume XI, No. 1, Juni 2019

karena ketidak jelasan sejarah ada pada zaman Nabi, dan fara kepemimpinan dalam memimpin suatu sahabat.

negara yang ditinggalkan oleh para Ideologi kelompok gairs keras pemimpin Islam terdahulu adalah totalitarian-sentralistik dan menjerumus kepada berbagai menjadikan agama sebagai refrensi penafsiran tentang kepemimpinan, teologis. Pandangan ideologis yang ada yang ingin mempertahankan bersifat totalitarian-sentralistik sistem khilafahan dan ada juga yang terhadap syari'ah membawa kepada solidaritas terhadap nation-state hal konsekuensi ketentuan hukum yang ini juga dipengaruhi oleh landasan totaliter dan sentralistik pula. Artinya, pemikiran yang berbeda-beda pula, hukum harus mengatur semua aspek sehingga melahirkan perbagai macam kehidupan umat tanpa terkecuali dan aliran dan perpecahan dalam kubu negara mengontrol pemahaman dan Islam itu sendiri seperti: Ikhwanul aflikasi secara menyeluruh pula. Oleh Muslimin, Jamaah Muslimin (at-Takfir sebab itulah klaim teologis yang Wa al-Hijrah), Jamaah Syabab mereka sampaikan sebenarnya Muhammad,Wahabi, dan sebagainya. menjadi manuver politik untuk Di-Indonesi sendiri kemunculan berlindung dari serangan siapa pun fundamentalisme mulai terlihat pasca dan sekaligus untuk menyerang siapa orde baru seperti cendawan di musim pun yang tidak mendukung atau hujan yang tumbuh dengan subur bahkan menetang mereka, yaitu; berkembang dan menjamur dalam agama menjadi alat mereka untuk kehidupan masyarakat, seperti FPI meraih kekuasaan. Mereka para garis (Front Pembela Islam), Majlis keras "tidak sesuai menaruh dan Mujahidin Idonesia), HTI (Hizbut Tahrir memanfaatkan keyakinan umat Indonesi), dan para kembarannya, manusia bahwa Allah swt, mengatur yang diantaranya ingin mendirkan semua aspek kehidupan manusia, negara kehalifahan dan memurnikan menjadikannya sebagai entry-point ajaran agama Islam sebagaiman yang bagi para pengikut garis keras untuk 
mengatur dan menguasai rakyat". Sedangkan agenda garis keras adalah menjadi wakil tuhan di bumi (khalifah allah fil-ardl). Padahal mereka yang bisa menjadi khalifah adalah meraka yang dalam beragama telah mencapai kualitas muhsinin dan mukhlisin, yakni para wali Allah.

Pada tahun 1924 M, adalah tahun terputusnya atau terhapusnya institusi Khalifah Islamiyah yang berdampak pada umat muslim sedunia kehilangan identitas religio-politik dan geopolitiknya. Kemudian negara-negara muslim berganti dengan model nationstate dalam berbangsa dan bernegara. Model ini adalah a-histori dalam pengalaman sejarah muslim. Kemudian dilema ini diterima secara faith accopli yang dikarenakan beberapa pembangunan; Pertama, teori politik Islam klasik dan abad pertengahan tidak memberikan konsep yang jelas dan detail tentang penyelenggaraan negara secara modern yang lebih mengedepankan pluralisme politik sehingga memberikan reinterpretasi yang varian bagi para pihak baik menerima maupun yang menolak konsep nationstate. Konsep nation-state merupakan sebuah pilihan yang tidak terhindarkan dan sebagai kenyataan yang harus dihadapi dalam politik modern. Kedua, peraktek dunia Islam pasca kolonialisme yang kemudian memperoklamirkan diri sebagai negara yang berdaulat dengan mengakui pluralisme politik dalam wilayah teritorial tertentu, menjadi sebuah konsensus dan kesadaran bersama dalam penerimaannya terhadap konsep nation-state. Ketiga, banyaknya para ulama dan pemimpinpemimpin Islam yang mendukung penerapan nation-state secara menyeluruh atau sebagian sebagai sesuatu yang alami dalam institusi politik yang bersifat keduniawian. ${ }^{5}$

Sebagaimana dikatakan Samuel P. Huntington, pada saat ini tengah terjadi gelombang demoratisasi ketiga dunia, setelah sebelumnya terjadi gelombang pertama tahun 1992 dan kedua tahun 1950-an. Gelombang ketiga ini diawali dengan runtuhnya

${ }^{5}$ Ahmad Yani Asrori, Menuju Khilafah Islamiyyah; Perjuangan Ikhwanul Muslimin, Yogyakarta: Syasat Press, 2008, hlm. 2. 
rezim Fasis di Portugal pada tahun 1974 dan mencapai puncaknya dengan runtunya komunisme di Eropa Timur dan Tengah pada akhir 1989. Menurut beberapa pengamat, itu berarti kemenangan bagi liberalisme ekonomi dan politik. Kemenangan bagi demokrasi. Demokrasi bukan lagi, seperti sebelumnya, sebagai sebuah ajaran parokial yang hanya dianut di Barat oleh prosentasi kecil bangsabangsa dunia, dan yang direalisasikan selama beberapa abad saja di sebagian amat kecil bumi. Dalam setengah abad terakhir ini, demokrasi dalam pengertian modern, telah memperoleh kekuatan hampir universal sebagai ide politik, sebagai sebuah inspirasi, dan sebuah ideologi.

Indonesi, demokratisasi dianggap sebagai agen, yang tak terelakkan, muncul pada ahir 1980-an (sebelumnya terjadi tahun 1950-an) dan mencapai puncaknya pada ahir 1990-an yang ditandai dengan lengsernya Soeharto, rezim militer yang menerapan sistem satu partai dominan selama kurang lebih 32 tahun. Sejak ahir tahun 1980-an itu terdapat kesadaran umum, paling tidak di tingkat elite, bahwa demokratisasi telah menjadi masalah kemanusiaan sejagat. Demokrasi adalah pilar peradaban. Bahkan, pada saat itu beberapa kalangan, semisal Onghokam, menilai jika Indonesi masih mempertahanan struktur politik yang berkembang masa orde baru merupakan sebuah negara yang melakukan anakronisme sendiri di dunia Asia Timur, selatan bahkan tenggara.

Namun demikian; pertama, di dunia Islam, termasuk di Indonesi, persoalan demokrasi masih menadi kontroversi di sebagian kecil kalangan. Ada yang menolaknya, ada yang menerima sepenuhnya, dan terahir ada yang menerima dengan catatan. Kedua, kendati secara ajaran, preferensi Islam lebih ke demokrasi, tetapi secara praktik di dunia Islam, negara yang dinilai para pengamat, khususnya barat, sebagai negara demokratis hanyalah turki, mali, dan Indonesi pasca reformasi. Beberapa pengamat menyebut juga Nigeria. Lary Diamond dan Juan Linz misalnya 
Komunike, Volume XI, No. 1, Juni 2019

menilai kebanyakan dunia Islam tidak bisa diharapkan dapat melakukan proses transisi ke demokrasi. Hal ini karena mayoritas (35) negara-negara muslim adalah negara otoriter dan sebagiannya (12 negara) adalah negara semi demokratis.

Demokrasi merupakan suatu sistem politik di mana para anggotanya memandang antara yang satu dengan yang lainnya sebagai orang yang sama dilihat dari segi politik. Mereka secara sama-sama berdaulat, baik secara langsung seperti pada awal kemunculannya di Athena, Yunani, maupun lewat pemilu presiden saat ini; atau mengingat ketidakmungkinan, lewat perwakilan yang dipilihnya secara bebas lewat pemilu sebagai sarana kontrol efektif mereka, seperti sekarang. Sama sekali bukan mayoritarianisme (pertimbangan mayoritas sebagai segalanya), tetapi menunung tinggi prinsip mayoritas yang di dalamnya tercakup kompromi yang adil, yang tidak mengganggu kepentingan atau hak-hak minoritas yang paling fundamental. Demokrasi majority rule, minority right. Suatu negara disebut demokratis, sejauh mana negara tersebut menjamin hak asasi manusia (seperti kebebasan menyatakan pendapat, berserikat dan berkumpul). Ini karena sistem demokrasi menolak diktatorisme (sistem kekuasaan yang angkuh atau sewenang-wenang), feodalisme (sistem kekuasaan tuan tanah yang mengharuskan ketundukan orang yang dikuasai tanpa kecuali), dan totalitarianisme (sistem politik yang serba menguasai hampir seluruh bidang kehidupan rakyat). Dalam demokrasi, hubungan antara penguasa dan rakyat bukanlah hubungan kekuasaan, melainkan berdasarkan hukum yang menjunjung tinggi HAM tersebut.

Demokrasi sering didefinisikan sebagai sistem politik dari rakyat, oleh rakyat dan untuk rakyat. Demokrasi dalam pergulatan pemikiran para tokoh Islam di Indonesi sebagaimana telah disinggung di atas, di Indonesi, pada saat ini sekalipun, pemikiran dari para tokoh pemikir Islam tentang demokrasi juga bisa kita petakan ke dalam tiga, sebagaimana di dunia 
Komunike, Volume XI, No. 1, Juni 2019

Islam lainnya. Yaitu, kalangan menolak demokrasi sepenuhnya, kalangan yang menerima tetapi mengakui adanya perbedaan, dan kalangan yang menerima sepenuhnya, di Indonesi, tampaknya, merupakan kelompok mayoritas.

Kalangan yang menolak sepenuhnnya demokrasi adalah Hizbut Tahrir Indonesi (HTI), sementara yang menerima tetapi mengakui adanya perbedaan adalah Mohammad Natsir sebagai pioner, yang dilanjutkan oleh Jalaludin Rahmat. Sedangan yang menerima sepenuhnya demokrasi adalah Nurcholish Madjid, Amien Rais, Syafi'i Ma'arif, Munawir Syadzali, dan Abdurrahman Wahid. Mereka adalah para tokoh penarik gerbong kelompok ketiga yang saat ini paling banyak pengikutnya.

Salah satu gerakan keagamaan yang berkembang cukup pesat dalam Indonesi kontemporer adalah Hizbut Tahrir Indonesi (HTI). Dengan mempertimbangkan beberapa aspek penting pada $\mathrm{HTI}$ seperti paham keagamaan, ideologi, dan gerakan sosialnya, HTI dapat dikategorikan sebagai gerakan keagamaan fundamentalis. Fundamentalisme pada tulisan ini digunakan sebagai sebuah tipe ideal untuk menjelaskan adanya gerakan religio-politik kontemporer yang berusaha kembali kepada dasardasar kitab suci,dan menafsirkan kembali fondasi-fondasi tersebut untuk diterapkan pada dunia politik dan sosial kontemporer. Corak fundamentalisme pada $\mathrm{HTI}$ terlihat pada cara pemahamannya terhhadap berbagai doktrin dalam kitab suci dan gerakan sosial yang di rancangnya untuk mewujudkan pemahaman tersebut dalam relitas politikdan sosial kontemporerterutama di Indonesi. Tulisan ini akan menyajikan diskusi yang menarik mengenai, antara lain: Sistem Demokrasi di Indonesi Dalam Persfektif Hizbut Tahir Indonesi.

\section{B. Islam dan Demokrasi di Indonesia}

Tidaklah mudah mengaitkan "Islam dengan Demokrasi"6 akan tetapi

6 Jikalau dikaji dalam pendekatan normatif dan empiris; pada tataran normatif yang mempersoalkan nilai-nilai demokrasi dari sudut pandang ajaran islam. Sementara dalam tataran empiris, menganalisis implementasi 
Komunike, Volume XI, No. 1, Juni 2019

tidak sedikit muslim yang berpandangan bahwa Islam sejalan dengan demokrasi. Dalam kaitannya ini, biasanya sejumlah prinsip-prinsip Islam dikemukakan, ditafsirkan dan kemudian disimpulkan bahwa nilainilai itu merupakan suatu semanat dengan pandangan profetik Francis Fukuyama-demokrasi. ${ }^{7}$ Prinsip umum yang ditawarkan didalamnya adalah keadilan ('adl), persamaan (musawah), musyawarah (syura) ${ }^{8}$, voluntarisme.

demokrasi dalam praktek politik dan ketatanegaraan. "Demokrasi pada sebagian sistem pemerintahan kita melarang didirikan partai-partai agama dan membiarkan pendiskreditan terhadap Islam dan kaum muslimin. Umat Islam dilarang menerbitkan surat kabar sebagai sarana mengemukakan pendapat atau untuk melakukan pembelaan diri. Bukan hanya itu, mereka pun dihilangkan karena mendirikan lembaga politik atau partai yang menampilkan pendapat mereka, meski sekedar menangkis orang-orang yang menyerang mereka dalam surat-surat kabar pemerintah serta propagandis asing. Demokrasi membela hak orang munafik dan orang-orang yang tidak beragama, mereka menguasai pusat-pusat informasi dan politik di bawah perlindungan militer sehingga mereka senantiasa mampu memonopoli pusat-pusat kekuatan pers setemat".

${ }^{7}$ Lihat Pemikiran Bahtiar Effendy Dalam Wajah-Wajah Islam Liberal di Indonesia, (Jakarta: Teater Utan Kayu, 2002), hlm. 36.

8 Pada dasarnya syura merupakan gagasan politik utama dalam al-Qur'an. Jika konsep syura ditransformasikan dalam kehidupan modern sekarang maka sistem
Sebagian umat Islam menganggap syura sebagai suatu wadah konsulatif dan syura merupakan metode yang berhubungan erat dengan akidah dan syari'at. Prinsip yang di bangun sebagai sebuah kerangka dasar dalam syura terletak pada pendirian yang menganggap bahwa ketundukan kepada Allah SWT merupakan sebuah kemutlakan dan tidak ada lagi yang harus dipatuhi selain daripada-Nya. Dengan cara ini, masyarakat Islam tetap terjaga dari ketundukan kepada kekuasaan dan hawa nafsu penguasa. Hal ini barangkali terkait langsung dengan banyaknya penguasa modern yang telah mendapat mandat dari rakyat, dengan mandat tersebut mereka memiliki kewenangan dalam membuat hukum dan mengatur

politik demokrasi lebih dekat dengan cita-cita politik qur'ani, sekalipun tidak selalu identik dengan praktek demokrasi barat. Syura bagi sebagian umat Islam dianggap sebagai lembaga politik yang paling penting untuk diadakan oleh negara-negara Islam (daulah Isamiyah).Beberapa gerakan Islam yang menekankan pada tradisi Islam periode awal ini terus memperjuangkan agar terbentuk kepemimpinan umat yang satu yang bisa menegakkan nilai-nilai Islam di atas muka bumi ini. Menurut pendukung gagasan ini hanya dengan khilafah Islamiyah sistem syura dapat terciptaLihat, Pemikiran dan Aksi Islam Indonesia, (Jakarta: Paramadina, 1995), hlm. 222. 
Komunike, Volume XI, No. 1, Juni 2019

masyarakat sesuai keinginannya, politik, politik Islam sendiri sebenarnya bahkan tidak sedikit diantara mereka tidak mengenal istilah demokrasi, yang mengkhianati rakyatnya. Untuk karena istilah ini diperkenalkan oleh menghindari perilaku tiran para Herodotus sekitar tigaribu tahun yang penguasa, syura merupakan jawaban lalu di Mesir Kuno yang kemudian atas kegalauan masyarakat modern berkembang oleh kalangan pemikir saat ini.

Sering dilupakan bahwa tidak Yunani Kuno pada masa klasik. Istilah sekedar mendakwahkan perinsipprinsip tersebut, akan tetapi juga yang lain- dan tidak semuanya mudah di akurkan dengan elemen-elemen dasar kehidupan yang demokratis. Bahkan, semua itu tergantung bagaimana orang menafsirkan prinsip-prinsip umum diatas yang secara taken for granted di anggap memiliki "kemiripan kekeluargaan" dengan demokrasi. "demokratia" yang diperkenalkan pada masa klasik di Yunani kuno adalah identik dengan institusi pengambil keputusan yang besifat kolektif yang terdiri dari demos atau rakyat yang ada dalam polis. Dalam pemikiran masyarakat Yunani kuno sebuah masyarakat yang demokratik haruslah paling tidak mencakup enam hal, pertama, adanya keharmonisan dari Menurut Affan Gaffar, kalangan Islam Indonesi sangat percaya dan mengharapkan demokrasi sebagaimana mestinya karena dengan demokrasi maka Islamic political cause dapat di perjuangkan sehingga dengan demikian kepentingan-kepentingan kepentingan masyarakat polis. Kedua, masyarakat polis haruslah bersifat homogen yang berkaitan dengan karakter mereka, jika tidak maka akan menimbulkan konflik yang sangat tajam di antara mereka. Ketiga, masyarakatnya tentu tidak saja tidak terlampau besar untuk menghindarkan Islam dalam arti luas (sosial, ekonomi, diri dari heterogenitas kepentingan. dan politik) akan dapat terlindungi Keempat, warga masyarakat punya dengan lebih baik. Affan Gaffar juga kebebasan untuk berkumpul dan menyebut bahwa dalam kosakata memutuskan hukum dan kebijakan 
bersama. Kelima, partisipasi kaum muslim dalam memahami masyarakat tidak dibatasi baik dalam ajaranlslamapakah doktrin-doktrin pembuatan keputusan maupun dalam teologis yang ada akan dicarikan administrasi pemerintahan, dan kesejajarannya dengan demokrasi atau keenam, polis tersebut haruslah tetap tidak. bersifat otonom. ${ }^{9}$

Segala suatu yang terpenting dari

Sedangkan demokrasi sendiri hal itu adalah bagaimana demokrasi suatu bentuk pemerintahan yang dipahami oleh komunitas Islam, dan berkembang pada abad delapan belas seperti apa pula para pendukung dan kesembilan belas di Eropa Barat demokrasi pada tingkat global melihat (laut). Yang demikian itu, menurut praktek-praktek demokrasi di dunia ilmuan politik konservatif lainnya, islam. Robert $\mathrm{N}$ Bellah Samuel P. Huntington, hanya bisa mendeskripsikan dinamika politik tumbuh karena dukungan "siap, nilai, masa muhammad sebagai suatu kepercayaan, dan pola-pola tingkah fenomena demokratis, tapi justru laku yang berkaitan dan kondusif bagi dipandang sebaliknya oleh banyak perkembangan demokrasi. Dari pihak-hata dikalangan muslim itu pernyataan di atas maka pertannyaan sendiri. ${ }^{10}$

yang timbul, dapatkah Islam, Menurut Syafii Maarif yang sebagaimana agama mayoritas mengambil dua konsep dari republik ini memberikan topangan Mohammad Iqbal dan Fazlur Rahman budaya bagi perkembangan dalam soal pelaksanaan demokrasi demokrasi? Disini jawbannya bisa khususnya pada masa orde baru di afirmatif atau negatif artinya memang Indonesi, demokrasi pancasila yang tidak ada jawaban mutlak dalam hal ini dicanangkan oleh orde baru, sacara karena semua itu tergantung kepada teoritis setidak-tidaknya adalah "demokrasi yang dibimbing oleh nilai

\footnotetext{
${ }^{10}$ Lihat Robert N. Bellah, Beyond Belief; Esei-Esei Tentang Agama di Dunia Modern, (Jakarta: Paramadina, 2000), hlm. 210.
} 
Komunike, Volume XI, No. 1, Juni 2019

pancasila dan UUD 1945. Sebagai melaksanakannya. Sikap pura-pura suatu sistem politik demokratik, harus kita hindari. Demokrasi seharusnya demokrasi pancasila lebih memerlukan contoh dalam praktik. longgar dibandingkan dengan Bila hanya berteori tentang demokrasi, demokrasi terpimpin", tetapi sedangkan dalam praktik "pengalaman selama lima belas tahun menampakkan sikap otoriter, berarti terakhir ini menunjukkan bahwa bahwa kita telah memberikan contoh harapan semacam ini masih sangat hipokrit kepada generasi yang sedang jauh dari kenyataannya, pemegang tumbuh. Jelas, cara itu bukan kekuasaan sesudah hancurnya pendidikan politik yang bertanggung Soekarno dan PKI boleh dikatakan jawab. ${ }^{11}$

dimonopoli oleh elite militer. Dalam perkembangannya, istilah "mungkin dengan maksud untuk demokrasi dikembangkan dalam mengamankan roda pembangunan, konteks yang paling modern dengan mereka masih sulit berlapang dada sejumlah indikator seperti partai dalam menghadapi perbedaan politik, kontrol terhadap pemerintah pendapat dalam isu-isu politik dan sebagainya.Dengan demikian, penting". Demokrasi pancasila harus masih menurut Afan Gaffar,Islamtidak bebas dari tekanan dan ancaman. mengenal kosa kata demokrasi sudah Selain itu, demokrasi pancasila pasti, karena dalam politiklslamhanya memerlukan keteladanan dalam mengenal istilah musyawarah sebagai praktek dan bukan hanya sekedar fondasi yang utama dalam kehidupan teori-teori demokrasi: politik.Dengan demikianlslamhanya Untuk mewujudkan demokrasi mengenal syura dan bukan demokrasi, pancasila, segala macam tekanan dan masalah ini telah ditegaskan al-Qur'an. ancaman harus kita buang dari budaya politik kita. Demokrasi hanya bisa tegak dengan kokoh bila kita siungguhsungguh membela

dan

${ }^{11}$ M. Syafi'i Anwar, Pemikiran dan Aksi Islam Indonesia; Sebuah Kajian Politik Tentang Cendikiawan Muslim Orde Baru, (Jakarta: Paramadina, 1995), hlm. 227. 
Syura, kalau ditelusuri akan sejarah kepemimpinan Islam, Taufiq ditemukan dasar pijakannya dalam al- Asy Syawi mengatakan: "Peniadaan Qur'an sebagai upaya membangun syura dalam sejarah negaramasyarakat ideal, masyarakat utama negaralslamhanyalah terbatas pada atau masyarakat madani (civil society), bidang politik dan pemerintahan. Allah menyebut masyarakat demikian Sedangkan di bidang legislatif dan dengan ungkapan, "Dan segala fakih, para ulama muslim dan ahli-ahli perkara mereka (diselesaikan melalui ijtihad mereka tetap melaksanakan sistem) musyawarah antara sesama mereka". ${ }^{12}$

syura dengan bebas tanpa campur tangan pihak penguasa".

Masa depan syura menurut Ashy Syawi tidak relevan dengan demokrasi yang dianut oleh Barat, karena syura tunduk kepada syari'at seperti halnya umat dan negara tunduk kepadanya.Sementara demokrasi memberikan kekuasaan dan keddaulatan kepada negara dan menganggap bahwa negara berkuasa atas tasyr'l wadh'l (hukum buatan manusia) secara mutlak dan tidak ada kaitannya dengan syari'at. Syura hanya berlaku dalam wilayah kekuasaan legislatif dan yudikatif. Dalam hal kekuasaan negara (pemerintahan) syura ditiadakan terutama dalam

12 Syarifuddin Jurdi, Pemikiran Politik Islam Indonesia; Pertautan Negara, Khilafah, Masyarakat Madani dan Demokrasi, (Yogyakarta: Pustaka Pelajar, 2008), hlm. 616617.

\section{Negara, Demokrasi dan Hizbut Tahrir Indonesia (HTI) \\ Berbicara masalah negara dan} pemerintahan dalam kacamata Islam memang suatu yang sangat menarik, dikatakan demikian, dikarenakan setiap komunitaslslammempunyai latar belakang yang berbeda dari segi sosial, ekonomi, budaya dan politik serta kemapuan penafsiran teks yang berbeda pula. Perbedaaan latar belakang ini melahirkan cara pandang atas teks yang berbeda. Meskipun teks yang dirujuk oleh masing-masing kelompoklslamitu satu (al-Qur'an dan sunnah), akibatnya melahirkan semacam fragmentasi pemahaman 
Komunike, Volume XI, No. 1, Juni 2019

keagamaan antara umat dengan pemimpin umat.

Dengan keragaman latar

belakang dan perbedaaan dalam menafsirkan teks itulah yang menyebabkan konsep-konsep umum tentang kehidupan politik jug beragam. Konsep suatu pemerintahan, misalnya, tidak slalu sama antar kalanganlslamitu sendiri, ada pihak Islam yang justru mendukung sepenuhnya sistem pemerintahan yang bersifat demokrasi dan menentang keras usaha-usaha yang menghendaki agar pemerintah terlibat dalam mengurus kehidupan keagamaan. Demikian sebalinya ada juga kalanganlslamyang dengan gigih tetap memperjuangkan agar negara dan pemerintahan dapat menerapakn sistem pemerintahan yang diatur dengan syari'at Islam, bahkan tidak hanya memperjuangkan tegaknya syari'at Islam, ada kalanganlslamyang justru memperjuangkan tegaknya khilafah islamiyah. ${ }^{13}$

${ }^{13}$ Luthfi Assyaukanie, Wajah Liberal Islam di Indonesia, (Jakarta: Teater Utan Kayu, 2002), hlm. 38.
Keragaman orientasi perjuangan tersebut tidak dimaksudkan sebagai kuatnya fragmentasi pemahaman keagamaan elite dan umat, meski harus diakui perbedaan itu telah melahirkan fragmentasi orientasi sosial politik para pengikut mazhab politik. Kehidupan Nabi telah dimaknai secara sangat beragam oleh umat islam. Perkembanganlslamdi dunia tidak pernah terlepas dari pengaruh politik yang berkembang saat itu, bahkan sejak agamalslampertama kali diperkenalkan di wilayah Arab yang dibawa oleh Nabi Muhammad saw, tidak secara langsung menampakkan profil politiknya. Ini dibuktikan bagaimana Nabi menguasai walayahwilayah Arab pada waktu itu dengan misi penyebaranIslamkesegenap penjuru dunia (Islamisasi World). Ada yang menyebut Nabi telah mendirikan "imperium" pemerintahan pertama bagi umat islam, karena itu merupakan kewajiban bagi umatlslamuntuk mengikuti sunnah Nabi dengan memperjuangkan suatu pemerintahan islam. Sebaliknya ada yang menyebut nabi tidak mendirikan pemerintah 
islamiyah melainkan suatu negara yang eksis di atas pluralitas masyarakat Madinah yang kemudian dikenal dengan Madinatun Nabi atau City State.

Memang sebelum era imperialisme, umat Islamsudah punya pengalaman menyelenggarakan pemerintah, bahkan semenjak Rasulullah berdomisili di Makkah. Setidaknya kita dapat mencatat era Rasulullah, era Khulafa al-Rasyidin, era Dinasti Umayyah, era Dinasti Abbasiyyah, dan era Usmani di Turki, Mughal di India dan Syafawi di Persia. Tiga pemerintahan yang sebut terakhir ini kurun waktunya berhimpit dengan era kaum imperialis menundukkan bumi orang timur yang sebagian besar umat Islam. Rasulullah sendiri tidak menerangakan bentuk dan sistem pemerintahan tertentu untuk dijadikan sebuah model dalam pemerintahan. Oleh karena itu timbul pertanyaan, apakah masih relevan sistem pemerintahan yang di gunakan oleh Rasulullah ketika sistem itu dibawa ke masyarakatlslamdibaggian timur, dan model negara yang bagaimanakah yang diinginkanlslamjika berhadapan dengan sistem dan tatanan sosial yang berbeda? Pertannyaan ini memiliki variansi jawaban yang berbeda dengan pola pemahaman yang berbeda pula. Masing-masing era mempunyai karakter tersendiri karena perubahan zaman dan tantangannya sekaligus. Oleh karena itu pada era pascaimperialisme terdapat sederetan variabel yang membedakan dari era sebelumnya. Namun demikian, bentuk negara dan sistem kepemerintahan yang manapun yang dipilih oleh komunitas muslim tertentu akan selalu membutuhkan rujukan otentik dalam setiap penyelenggaraan negara Islam, bagaimana Rasul meyelenggarakan pemerintahan. Sebagaimana yang disebutkan bahwa beliau tidak menunjukkan model pemerintahan tertentu tetapi menyediakan prinsipprinsip serta etik dan itulah yang seharusnya dijadikan acuan. ${ }^{14}$

Mendirikan suatu negara atau pemerintahan untuk mengelola urusan rakyat (umum) merupakan kewajiban

${ }^{14}$ M. Zuhri, Potret Keteladanan Kiprah Politik Muhammad Rasulullah (Yogyakarta: LESFI, 2004), hlm. V. 
Komunike, Volume XI, No. 1, Juni 2019

agama yang paling agung, karena formal maupun informal, yang agama tidak mungkin tegak tanpa membuat dan mempertahankan negara atau pemerintahan. Ukuran simbol-simbol dan lembaga tersebut. tegaknya suatu nilai-nilai agama Penafsiran simbol-simbol dilakukan seperti keamanan, keadilan, dengan menghadapkan dengan latar keteraturan dan keadaban hanya belakangnya yang, sementara bisa mungkin dilakukan melalui negara atau dipengaruhi nuansa kontekstual, biasa pemerintahan. Menurut Ibn Taimiyah, bagi muslim diseluruh dunia. ${ }^{16}$ Sistem bahwa umat manusia tidak akan politik, baik di dunia muslim atau mungkin mencakupi segala dimanapun, tidak bisa menghindari kebutuhannya tanpa kerja sama dan manajemen persaingan bahkan selalu saling membantu dalam kehidupan identik di tunggangi dengan kelompok, dan setiap kehidupan kepentingan.

kelompok atau bermasarakat Oleh sebab ketidak jelasan memerlukan seorang kepala atau sejarah kepemimpinan dalam pemimpin. Kehadiran seorang memimpin suatu negara yang pemimpin dalam suatu masyarakat, ditinggalkan oleh para kelompok, bangsa dan negara pemimpinIslamterdahulu menjerumus merupakan suatu yang tidak kepada berbagai penafsiran tentang terelekkan, yang mengemban tugas kepemimpinan, ada yang ingin sebagaimana yang diperintahkan mempertahankan sistem khilafahan agama, untuk menegakkan amar dan ada juga yang solidaritas terhadap ma'ruf nahi munkar. ${ }^{15}$ nation-state hal ini juga dipengaruhi Politik muslim melibatkan oleh landasan pemikiran yang perlombaan dan persaingan penafsiran berbeda-beda pula, sehingga simbol dan kontrol atas lembaga, baik melahirkan perbagai macam aliran dan

15 Syarifuddin Jurdi, Pemikiran Politik Islam Indonesia; Pertautan Negara, Khilafah, Masyarakat Madani dan Demokrasi, (Yogyakarta: Pustaka Pelajar, 2008), hlm. 14.
16 Dale F. Eickelman dan James Piscatori, Politik Muslim; Wacana Kekuasaan dan Hegemoni Dalam Masyarakat Muslim, (Yogyakarta: Tiara Wacana, 1998), hlm. 6. 
Komunike, Volume XI, No. 1, Juni 2019

perpecahan dalam kubulslamitu

saat ini tidak sama dengan islam".

sendiri seperti: Ikhwanul Muslimin, Sistem

pemerintahanIslamtidak

Jamaah Muslimin (at-Takfir Wa al-

mengenal warisan kekuasaan, tidak Hijrah), Jamaah Syabab mengenal kedaulatan ditangan rakyat, Muhammad,Wahabi, dan sebagainya. tidak mengenal pemerintahan dibagi Di Indonesi sendiri kemunculan berdasarkan wilayah otonomi, juga fundamentalisme mulai terlihat pasca tidak memberikan keistimewaan orde baru seperti cendawan di musim kepada wilayah atau hak-hak khusus hujan yang tumbuh dengan subur kepada wilayah tertentu. ${ }^{17}$ Sistem berkembang dan menjamur dalam pemerintahan islam, menurut kehidupan masyarakat, seperti FPI kalangan pendukung ide an- Nabhani, (Front Pembela Islam), Majlis merupakan sistem kesaatuan yang Mujahidin Idonesia), HTI (Hizbut Tahrir terpusat di satu tangan yaitu Khalifah Indonesi), dan para kembarannya, (imam). Khalifah itu sendiri merupakan yang diantaranya ingin mendirkan seseorang yang memperjuangkan negara kehalifahan dan memurnikan keadilan rakyat tidak memiliki hak-hak ajaran agamalslamsebagaiman yang khusus, haknya sama dengan rakyat ada pada zaman $\mathrm{Nabi}$, dan fara yang diperjuangkannya atau sahabat.

Beberapa kalanganlslamyang dipimpinnya.

Dalam pandangan Hizbut Tahrir, beroientasi "fundamentalis" Islam merupakan ideologi bagi negara, menganggap bahwa sistem pemerintahan islamiyah yang unggul dan memberikan jaminan yang adil bagi warga negara. Hal ini dapat kita telaah dalam argumentasi Taqiyuddin an-Nabhani, pendiri dan tokoh yang di idolakan oleh jamaah Hizbut Tahrir "semua sistem pemerintahan yang ada

17 Kalau demikian, sistem politik pemerintahan islam yang dikenal dengan kerajaan, warisan kekuasaan atau yang demikiannya sehingga banyak pengamat islam "sekuler" menganggapnya tidak demokratis, karena tidak pernah ada model pemerintahan islam yang betul-betul demokratis dan pemimpinnya dipilih secara bebas oleh rakyat. Kemungkianan masa khulafauur rasyidun merupakan pengecualian. Lihat; Syarifuddin Jurdi, Pemikiran Politik Islam Indonesia; Pertautan Negara, Khilafah, Masyarakat Madani dan Demokrasi, (Yogyakarta: Pustaka Pelajar, 2008), hlm. 9-10. 
Komunike, Volume XI, No. 1, Juni 2019

bagi masyarakat dan bagi kehidupan merupakan cara Hizbut Tahrir umat manusia,Islamadalah bagian menyuarakan gagasan politik Islamnya. integral yang mengatur seluruh aspek Menurut salah seorang pengurusnya, kehidupan umat manusia.Islamjuga Hizbut Tahrir tidak akan menjadi partai telah memerintahkan untuk politik untuk saat ini di Indonesi, tetapi mendirikan suatu negara dan akan berjuang secara pemerintahannya, dan memerintah ekstraparlementer. Kelembagaan dengan hukum-hukumlslamdan bukan politik Indonesi menurutnya hukum buatan manusia yang tidak menyulitkan sekaligus tidak efektif bersumber pada Islam. Al-Qur'an telah bagi Hizbut Tahrir untuk menegaskan dalam (QS. an-Nisa 4: 89) memperjuangkan gagasan khilafah "Taatilah Allah dan taatilah Rasulullah, Islamiyah, bahkan muncul "ketakutan" serta ulil amri (para pemimpin di akan terjerumus ke dalam anatara kalian)".Dan mengenai kepentingan-kepentingan politik penegakan hukum "maka putuskanlah sesaat yang justru akan mengurangi perkara mereka menurut apa yang bobot perjuanganlslammasa depan.

Allah turunkan. Dan jangan kamu Konsep pemerintahanIslamakan mengikuti hawa nafsu mereka dengan terus diperjuangkan meski saat ini meninggalkan kebenaran yang telah masih bersifat ekstraparlementer datang kepadamu" (QS. al-Maidah 5: dengan menggelar seminar, dialog, 48), dari ayat tersebut telah jelas diskusi, tabligh akbar, demonstrasi dan mengenai ketentuanlslamtentang rapat-rapat umum. Gerakan ini tidak pemerintahan dan proses bersifat lokal (negara) tetapi menyebar penyelenggaraannya. keseluruh belahan dunia dan pendiri Dalam konteks Indonesi, Hizbut jama'ah ini Taqiyuddin an-Nabhani Tahrir baru pada tingkat gerakan moral telah meninggalkan beberapa konsep politik yang dilakukan dalam berbagai pemerintahanlslamyang oleh kegiatan terutama melalui tablig akbar pengikutnya akan terus diperjuangkan dan demonstrasi, dua hal inni hingga terealisasi. Hizbut Tahrir 
Komunike, Volume XI, No. 1, Juni 2019

Indonesi masih memprioritaskan Hizbut Tahrir harus berada dalam pembinaan jam'ah, menurut salah suatu payung politik yakni di bawah seorang yang aktif dalam Hizbut Tahrir, naungan Daulah Islamiyah, yaitu suatu saat Hizbut Tahrir Indonesi akan Daulah Khilafah, yang dipimpin oleh menjadi kekuatan politik resmi untuk seorang Khalifah yang diangkat dan di dapat memperjuangkan cita-cita bai'at oleh kaum muslimin untuk politiknya.

didengar dan ditaati agar menjalankan

Tahapan yang paling penting pemerintahan berdasarkan Kitabullah bagi Hizbut Tahrir untuk memudahkan dan Sunnah Rasul-nya, dan pelaksanaan syari'atlslamadalah mengemban risalah Islam keseluruh Istilamul Hukmi (pengambilalihan penjuru dunia dengan dakwah dan kekuasaan).Tingkat terakhir ini jihad.

merupakan fase di mana perjuangan Setelah Daulah Islamiyah umatlslamsudah mencapai target yang terbentuk, menurut Hizbut Tahrir, diinginkannya, karena bagi Hizbut akan menjadi kekuatan dunia yang Tahrir ketika mencapai tingkatan ini, besar yang sulit ditandingi oleh maka umatıslamakan dengan leluasa kekuatan-kekuatan mana pun mengatur kehidupan umat dan juga.Umatlslamsetelah mencapai pemerintahan berdasarkan prinsip- tujuan ini, harus melakukan berbagai prinsip Islam. Bagi Hizbut Tahrir, upaya dan langkah yang sistematik tahapan ini merupakan proses untuk merumuskan berbagai perjuangan yang dibantu dan diberi perangkat keras dan lunak pertolongan oleh Allah. Setelah penyelenggaraan negara dalam khilafah terbentuk, maka kaum pemerintahan Islam. Jadi puncak dari muslimin sudah mmemulai perjuangan yang paling ditunggumensosialisasikan ide-ide, pandangan tunggu oleh Hizbut Tahrir adalah dan konsep-konsepnya berdasarkan terbentuknya kepemimpinan tunggal ajaran-ajaran Islam. Membangun Islam, hanya dengan khilafah sajalah kejayaan umat menurut pendapat 
dalam pandangan Hizbut Tahrir hukum Islam dapat ditegaskan.

\section{Diantara}

fundamentalisme Islam yang berkembang di Indonesia, Hizbut Tahrir memiliki visi universalistik yang paling menonjol. Ambillah perbandingan dengan Gerakan Tarbiyah. Menurut beberapa penelitian, Gerakan Tarbiyah selalu disebut sebagai gerakan Islam kontemporer yang mendapat pengaruh kuat dari Ikhwan alMuslimin. Maka tidak heran jika Gerakan Tarbiyah sering disebut juga nama organisasi yang didirikan oleh Hasan al-Banna tersebut. Sebagaimana Ikhwan al-Muslimin, Gerakan Tarbiyah juga memiliki agenda politik seperti penerapan syari'at Islam dan negara Islam. Tetapi sebagaimana dalam kategori R. Hrair Dekmejian, orientasi gerakan Ikhawn al-Muslimin masih lebih tegas Hizbut Tahrir. Sikap tegas Hizbut Tahrir nampak pada pandangannya bahwa daulah khilafah Islam merupakan prasyarat utama penerapan syari'at Islam. Dengan kata lain, syari'at Islam bisa diterapkan jika sudah terwujud daulah khilafah Islam. Hal ini agak berbeda dengan Ikhwan alMuslimin yang juga menjadi sikap politik Gerakan Tarbiyah. Kategori yang dibuat oleh Dekmejian untuk Ikhwan al-Muslimin adalah gradualisadap-tasionis. Dengan kategori ini, Dekmejian ingin menjelaskan, meskipun tetap mengagendakan penerapan syari'at Islam, tetapi tidak perlu menunggu terwujudnya negara Islam sebagaimana menjadi pendirian Hizbut Tahrir. ${ }^{18}$

Selain bisa dilihat dari orientasi politik dan cara memahami doktrin agama, corak fundamentalis Hizbut Tahrir juga kelihatan pada sikapnya terhadap modernitas. Seperti dikemukakan oleh Euban, dalam fundamentalisme terdapat ciri yang bisa dibilang ambigu terhadap modernitas. Di satu sisi fundamentalisme bersikap keras dan reaksioner terhadap modernitas, tetapi disisi lain, fundamentalisme sebagai ekspresi dari modernitas.

18 Syamsul Arifin, Studi Islam Ontemporer; Arus Radikalisasi dan Multikulturalisme di Indonesia, (Malang: Instans Publising, 2015), hlm. 109. 
Hizbut Tahrir berada dalam sikap yang demikian dalam menghadapi modernitas. Kesimpulan seperti didasarkan pada dua kategori konseptual dalam Hizbut Tahrir yaitu, hadarah dan madaniyyah. Hadarah merupakan sekumpulan persepsi tentang kehidupan atau semacam way of life. Sedangkan madaniyyah adalah bentuk-bentuk fisik (benda) yang digunakan dalam aktivitas kehidupan. Dari aspek hadarah, Hizbut Tahrir memposisikan secara binaryopposition antara Islam dengan Barat serta hadarah lainnya. Oleh karena itu, Hizbut Tahrir melarang kepada umat Islam mengambill sesuatu dari Barat seperti konsep demokrasi, pluralisme, sistem ekonomi kapitalisme, dan lain sebagainya. Tetapi terhadap madaniyaah Hizbut Tahrir membolehkan untuk mengambil manfaatnya. Hasil dari madaniyyah ini misalnya kemajuan dibidang transportasi, pertanian, komunikasi, dan lain sebagainya. Menurut Hizbut Tahrir, seluruh hasil kemajuan tersebut bersifat universal sehingga siapapun boleh mengambil manfaatnya. Hizbut
Tahrir bahkan memberikan justifikasi dengan hukum fardu kifayah untuk mengambil manfaat dari madaniyyah. Para akktivis HTI dalam menolak demokrasi mengikuti pendapat yang disampaikan pendirinya di Timur Tengah, yaitu 'Abd al-Qadim Zallum. Baginnya dan juga HTI, demokrasi adalah sistem kufur atau nonlslam(addimuqarytiiyah nizham kufr) yang bertentangan dengan Islam. Argumennya antara lain adalah: karena demokrasi adalah produk akal manusia, bukan Tuhan; bagian dari akidah sekularisme (pemisahan agama dan negara); dalamlslamkedaulatan ada di tangan syari'at, bukan di tangan rakyat; dalam Islam, prinsip mayoritas tidaklah memiliki signifikansi, karena yang signifikan adalah teks-teks syari'at; dan kebebasan seperti kebebasan beragama dalam Islam, menurutnya, tidak ada, karena orang murtad yang tidak bertaubat dalam fikih harus dihukum mati. Sekalipun ada kesamaan, hanya kebetulan saja karena prinsipnya berbeda. 
Komunike, Volume XI, No. 1, Juni 2019

\section{Kesimpulan}

Dari penjelasan diatas, kita dapat melihat potret kehadiran Hizb sebagai fenomena baru dalam sejarah perpolitikan dunia dan terutama kehadiran Hizb di Indonesia dengan isu-isu "monumental" nya mengenai khilafah Islamiyah atau daulah Islamiyah. Gagasan ideal, simpati dan spektakuler yang diusung oleh Hizb, walaupun gagasan itu pada dasarnya merupakan gagasan lama yang telah diperaktikkan oleh umat Islam sejak zaman Nabi, Khulafaur Rasyidin dan khalifah-khalifah setelahnya tetapi untuk konteks politik global saat ini merupakan ide yang sedikit mengundang "kekhawatiran" dan "pesimisme", karena dalam realitas kehidupan politik umat masih sulit untuk menghadirkan wacana politik Islam. Seperti telah dijelaskan sebelumnya, Indonesia merupakan bangsa yang mayoritas penduduknya beragama Islam, tapi hingga kini masih sulit sulit untuk menerapkan hukum Islam dalam kehidupan sosial, ekonomi, politik dan hukumnya. Kondisi ini diperparah oleh banyaknya umat Islam yang juga memiliki pandangan bahwa Islam tidak perlu diatur atau mengatur negara, biarkanlah urusan agama menjadi urusan pribadi dan kelompok keagamaan yang akan membinanya, sementara negara cukup mengatur kehidupan bersama dalam masyarakat. Kekuatan asing yang berkolaborasi dengan kelompok dalam negeri tidak ingin melihat Indonesia menjadi bangsa besar, bangsa yang kuat, apalagi letak kekuatannya pada umat Islam. Kalau Islam berhasil diwujudkan dalam politik resmi kenegaraan, akan menjadi ancaman bagi pihak asing yang punya rencana untuk mengeksploitasi sumber daya alam negeri yang kaya ini dan sekaligus menjadikan Indonesia sebagai market ekpansion produk-produk kapitalisme Barat. Gagasan Hizb Tahrir mengenai khilafah Islamiyah atau daulah Islamiyah, meskipun masih jauh dari harapan, tetapi bermanfaat bagi pendidikan politik umat Islam. Dalam kurun waktu lima atau satu dekade mendatang, umat Islam masih sulit menyatukan visi dan pandangan 
mengenai kehidupan sosial dan politik. Barangkali buat Hizb Indonesia alangkah bijak, arif, dan baik kalau mengedepankan fungsi penyadaran umat dan pembinaan sebagaimana yang juga dipahami oleh Hizb dilakukan secara serius dan terencana dengan baik. Penyadaran ini merupakan sesuatu yang penting bagi proses perwujudan misi Islam yaitu tegakkan masyarakat yang berdasarkan nilai-nilai Islam.

\section{Daftar Pustaka}

Ahmad Yani Asrori, Menuju Khilafah Islamiyyah; Perjuangan Ikhwanul Muslimin, Yogyakarta: Syasat Press, 2008.

Dale F. Eickelman dan James Piscatori, Politik Muslim; Wacana Kekuasaan dan Hegemoni Dalam Masyarakat Muslim, Yogyakarta: Tiara Wacana, 1998.

Ghufron A. Mas'adi Sebagai Pengantar Penerjemah Dalam Ira. $M$. Lapidus, Sejarah Sosial Umat Islam, Jakarta: PT RajaGrafindo Persada, 1999.

Luthfi Assyaukanie, Wajah Liberal Islam di Indonesia, (Jakarta:
Teater Utan Kayu, $2002^{1}$ Pemikiran dan Aksi Islam Indonesia, (Jakarta: Paramadina, 1995), hlm. 222.

M. Syafi'i Anwar, Pemikiran dan Aksi Islam Indonesia; Sebuah Kajian Politik Tentang Cendikiawan Muslim Orde Baru, Jakarta: Paramadina, 1995.

M. Zuhri, Potret Keteladanan Kiprah Politik Muhammad Rasulullah, Yogyakarta: LESFI, 2004.

Masykuri Abdullah, Demokrasi Dipersimpangan Makna Respon Intelektual Muslim Indonesia Terhadap Konsep Demokrasi 1966-1993, Yogyakarta: Tiara Wacana, 1999.

Robert N. Bellah, Beyond Belief; EseiEsei Tentang Agama di Dunia Modern, Jakarta: Paramadina, 2000.

Sukron Kamil, Islam dan Politik di Indonesia Terkini, Jakarta: PSIA UIN Jakarta, 2013.

Syamsul Arifin, Studi Islam Ontemporer; Arus Radikalisasi dan Multikulturalisme di Indonesia, Malang: Instans Publising, 2015.

Syarifuddin Jurdi, Pemikiran Politik Islam Indonesia; Pertautan Negara, Khilafah, Masyarakat Madani dan Demokrasi, Yogyakarta: Pustaka Pelajar, 2008. 